\title{
KESESUAIAN LAHAN KOMODITAS HORTIKULTURA DI DESA HATIVE BESAR KECAMATAN TELUK AMBON
}

\section{Land Suitability for Horticultural Commodities in Hative Besar Village, Teluk Ambon Sub District}

\author{
Vinda V. Tentua ${ }^{1}$, Husein Salampessy ${ }^{2}$ dan Johanis P. Haumahu ${ }^{2, *}$ \\ ${ }^{1}$ Program Studi Agroteknologi, Jurusan Budidaya Pertanian, Fakultas Pertanian, Universitas Pattimura \\ ${ }^{2}$ Jurusan Budidaya Pertanian, Fakultas Pertanian, Universitas Pattimura \\ Jl. Ir. M. Putuhena, Kampus Poka Ambon, 97233 \\ *Penulis Korespondensi: E-mail: johannishaumahu@gmail.com
}

\begin{abstract}
This study aimed to determine the land suitability for horticultural commodities based on physical condition data of the land, to determine the limiting factors in the field and to give recommendation to improve the land use for horticultural commodities. This research was conducted in Hative Besar Village, Teluk Ambon Sub District in September-October 2016. This research was divided into three phases: preparatory phase of research which included secondary data collection and digitizing land unit map, field research stage covering primary data collection or field checking using free survey techniques, as well as data analysis and reporting stages that will be revealed in maps and land suitability for horticultural commodities as well as recommendations for improvement of the limiting factors. The results showed that based on the actual land suitability assessment there were only five suitable plants is rambutan, gandaria, durian, $d u k u$ and pineapple. Whereas based on the actual suitability of the selected land, the appropriate plants were durian, duku and pineapple. The results of the study also indicate that there were several limiting factors, namely the availability of water, the availability of oxygen, rooting media and erosion hazard that can be improved by applying soil and water conservation techniques.
\end{abstract}

Keywords: horticultural crops, land suitability evaluation

\begin{abstract}
ABSTRAK
Penelitian ini bertujuan untuk menentukan kesesuaian lahan komoditas hortikultura berdasarkan data kondisi fisik lahan, menentukan faktor-faktor pembatas yang terdapat di lapangan serta menentukan tindakan rekomendasi perbaikan untuk komoditas hortikultura. Penelitian ini dilaksanakan di Desa Hative Besar Kecamatan Teluk Ambon pada bulan september - oktober 2016. Penelitian ini terbagi menjadi tiga tahap yakni tahap persiapan penelitian yang meliputi pengumpulan data sekunder dan mendigitasi peta satuan lahan, tahap penelitian lapangan yang meliputi pengumpulan data primer atau pengecekan lapangan dengan menggunakan teknik survei bebas, serta tahap analisis data dan pelaporan yang akan menghasilkan peta dan kesesuaian lahan untuk komoditas hortikultura serta rekomendasi perbaikan faktor pembatas. Hasil penelitian menunjukkan bahwa berdasarkan hasil penilaian kesesuaian lahan aktual keenam tanaman tersebut termasuk dalam kelas kesesuaian S3 dan hasil penilaian kesesuaian lahan potensial hanya terdapat lima tanaman yang sesuai yakni rambutan, gandaria, durian, duku dan nenas. Sedangkan berdasarkan kesesuaian lahan aktual terpilih, tanaman yang sesuai yaitu durian, duku dan nenas. Hasil penelitian juga menunjukkan bahwa terdapat beberapa faktor pembatas yakni faktor ketersediaan air, ketersediaan oksigen, media perakaran dan bahaya erosi yang dapat dilakukan perbaikan dengan menerapkan teknik konservasi tanah dan air.
\end{abstract}

Kata kunci: evaluasi kesesuaian lahan, tanaman hortikultura

\section{PENDAHULUAN}

Meningkatnya kebutuhan dan persaingan dalam penggunaan lahan baik untuk keperluan produksi pertanian maupun untuk keperluan lainnya memerlukan pemikiran bijaksana mengenai kegiatan pertanian berkelanjutan sehingga dapat menghasilkan suatu keputusan yang efisien dalam pemanfaatan sumberdaya lahan yang terbatas serta dapat dilakukan suatu tindakan konservasi yang berguna bagi masa mendatang (Sitorus, 1985).

Pembangunan pertanian sangat tergantung pada kondisi sumberdaya wilayah, baik kondisi fisik, hayati maupun manusia. Oleh karena itu di dalam menentukan arah pembangunan di bidang pertanian perlu diidentifikasi secara cermat karakteristik spesifik 
wilayah, yang meliputi sumberdayanya maupun dampak pembangunan yang telah dicapai pada wilayah tersebut. Sektor pertanian diharapkan mampu memberikan sumbangan yang berarti dalam peningkatan pendapatan nasional. Sektor ini berperan sebagai sumber penghasil bahan pangan, sumber bahan baku bagi industri, mata pencaharian sebagian besar penduduk, penghasil devisa negara dari ekspor komoditas bahkan berpengaruh besar terhadap stabilitas dan keamanan nasional (Suprapto, 2010).

Usaha pertanian sangat memerlukan lahan yang sesuai dalam mengembangkan dan mengusahakan suatu tanaman tertentu. Secara ideal lahan yang sesuai untuk usaha pertanian ialah lahan yang mempunyai kecocokan antara potensi lahan dengan syarat tumbuh optimal suatu jenis tanaman pertanian. Dalam pemanfaatan lahan pertanian diperlukan tindakan yang intensif dan bijaksana sehingga pemanfaatan lahan pertanian senatiasa berlangsung dengan memperhatikan karakteristik dan kondisi lahan, dikarenakan setiap lahan memiliki karakteristik dan kondisi yang berbeda-beda. Dengan memperhatikan karakteristik dan kondisi lahan pertanian diharapkan dapat memperbaiki peningkatan produktivitas yang optimal di sektor pertanian karena berhasilnya suatu peningkatan produksi pertanian tergantung pada perencanaan peggunaan lahan yang sesuai dengan kemampuan lahannya.

Safitri (2015) mengemukakan bahwa pada saat ini banyak masyarakat (petani) yang membudidayakan suatu tanaman tanpa mengetahui tingkat kesesuain lahan dengan tanaman yang mereka tanami. Termasuk untuk tanaman hortikultura banyak petani yang membudidayakan tanaman hortikultura akan tetapi mereka tidak mengetahui apakah lahan yang mereka tanam cocok untuk ditanami hortikultura atau tidak. Hal ini disebabkan karena kurangnya pengetahuan masyarakat khususnya petani mengenai ilmu tentang penggunaan lahan atau kesesuaian penggunaan lahan. Untuk mengetahui tingkat kesesuaian lahan dengan tanaman maka perlu dilakukan evaluasi kesesuaiannya. Kesesuaian lahan adalah tingkat kecocokan sebidang lahan untuk penggunaan tertentu. Kesesuaian lahan tersebut dapat dinilai untuk kondisi saat ini (kesesuaian lahan aktual) atau setelah diadakan perbaikan (kesesuaian lahan potensial) (Ritung et al., 2007). Evaluasi kesesuian lahan dilakukan dengan metode matching yaitu dengan mencocokkan serta memperbandingkan antara data karakteristik lahan dari lapangan dan laboratorium dengan kriteria kesesuaian lahan untuk tanaman padi sawah (Balai Penelitian Tanah, 2003). Secara spesifik, kesesuain lahan untuk suatu komoditas dinilai berdasarkan sifatsifat fisik lingkungan, seperti tingkat kesuburan tanah, iklim, topografi, hidrologi dan draenase (Supriyadi et al., 2009 dalam Mutiara, 2015).

Pemilihan komoditas pertanian untuk dilaksanakan pada suatu wilayah tergantung pada kondisi agroekosistem wilayah, kondisi agribisnis komoditas, serta kondisi sosial ekonomi dan budaya masyarakat. Dengan demikian diharapkan agar komoditas yang dikembangkan pada suatu wilayah dapat memiliki tingkat kesesuaian lahan yang tinggi dan memiliki nilai keunggulan komparatif serta bisa diterima dan dikembangkan oleh masyarakat, dengan pertimbangan prospek pemasarannya. Penilaian tingkat kesesuaian lahan bagi berbagai komoditas pertanian ditentukan berdasarkan kualitas dan karakteristik lahan daerah tersebut, yang memberikan gambaran tentang kebutuhan ekologis dari komoditi yang diusahakan. Melalui penilaian tingkat kesesuaian lahan bagi berbagai komoditas pertanian seperti kelompok tanaman hortikultura dapat ditetapkan jenis-jenis tanaman yang sesuai pada suatu wilayah (Gaspersz, 2008).

Hative Besar merupakan salah satu desa dengan luas $30,00 \mathrm{~km}^{2}$, dan merupakan desa terluas di wilayah Kecamatan Teluk Ambon. Hative Besar juga terkenal dengan berbagai komoditas pertanian, salah satunya yang dikembangkan secara alamiah tanpa budidaya khusus adalah kelompok tanaman hortikultura. Tanaman hortikultura dalam hal ini jenis buah-buahan yang dihasilkan dari desa tersebut yakni: durian (Durio zibetinus MURR), gandaria (Bouea maccrophylla Griffith), duku (Lansium domesticum CORR), manggis (Garcinia manggostana LINN), rambutan (Nephelium lappaceum LINN), nenas (Ananas comosus L. MERR.) dan lain-lain. Namun dari jenis-jenis tanaman buahbuahan tersebut, sampai saat ini belum diketahui jenis tanaman yang sesuai dengan kondisi fisik lahan lokasi penelitian.

Penelitian ini bertujuan untuk menentukan Kesesuaian Lahan komoditas hortikultura berdasarkan data kondisi fisik lahan, menentukan faktor-faktor pembatas yang terdapat di lapangan dan menentukan rekomendasi kesesuaian aktual terpilih tanaman hortikultura di Desa Hative Besar. Sehingga akan menghasilkan kesesuaian lahan untuk komoditas hortikultura, peta Kesesuaian Lahan untuk komoditas hortikultura dan tindakan rekomendasi perbaikan untuk komoditas hortikultura.

\section{METODE PENELITIAN}

\section{Tempat dan Waktu Penelitian}

Kegiatan penelitian ini dilaksanakan di Desa Hative Besar Kecamatan Teluk Ambon pada bulan September sampai dengan Oktober 2016. Lokasi penelitian dapat dilihat pada Peta Lokasi Daerah Penelitian Gambar 1.

\section{Bahan dan Alat Penelitian}

Bahan yang digunakan dalam penelitian ini adalah: peta Satuan Lahan Kota Ambon dengan skala 1:50.000, kartu deskripsi profil tanah di lapangan, $\mathrm{pH}$ indikator dan larutan $\mathrm{H}_{2} \mathrm{O}_{2}$. Peralatan yang digunakan untuk penggambaran peta adalah: Software Arc Gis versi 10.1 , scaner untuk input data dalam pembuatan peta, dan printer untuk pencetakan peta. 


\section{Desain dan Prosedur Penelitian}

Penelitian ini terbagi menjadi tiga tahap yakni: 1) tahap persiapan penelitian; 2) tahap penelitian lapangan; dan 3) tahap analisis data dan pelaporan.

\section{Tahapan Persiapan Penelitian}

Hal-hal yang perlu disiapkan guna mendukung berlangsungnya penelitian ini adalah sebagai berikut: 1) pengumpulan data sekunder berupa Peta dasar dan data statistik Ambon dalam Angka tahun 2015, dan beberapa penelitian yang sudah ada sebelumnya; dan 2) mendigitasi peta Satuan Lahan yang dijadikan peta kerja lapangan Peta ini dibuat secara digital dengan program ArcGis.

\section{Tahapan Penelitian Lapangan}

Di dalam kegiatan penelitian ini, dilakukan proses identifikasi komponen satuan lahan (Land Unit) berdasarkan teknik-teknik pelaksanaan berikut ini: 1) Pengecekan lapangan dengan metode survei lapangan, yang menggunakan teknik survei bebas yang dilakukan secara intensif pada daerah contoh (sample area) dan pengecekan tambahan di luar daerah contoh; dan 2) Pengamatan dan analisis karakteristik dan kualitas lahan pada setiap satuan lahan di lapangan dengan menggunakan Bor/Auger, kompas, abney level, altimeter, pacul, sekop, GPS, meter roll, pisau lapangan, dan alat tulis.

\section{Analisis Data dan Pelaporan}

Setelah diperoleh informasi fisik lahan dan maka langkah berikutnya adalah proses analisis data dan pelaporan sebagai berikut: 1) penetapan persyaratan Tipe Penggunaan Lahan yang dievaluasi/diusulkan; 2) analisis kesesuaian lahan untuk penentuan Tipe Penggunaan Lahan (TPL) atau kelompok jenis-jenis komoditi pertanian, yaitu: kelompok tanaman hortikultura berdasarkan kriteria CSR/FAO Staff (2000); dan 3) penetapan evaluasi kesesuaian lahan dilakukan dengan metode matching yaitu dengan cara mencocokkan serta memperbandingkan antara data karakteristik dan kualitas lahan dengan kesesuaian lahan tanaman hortikultura yang telah diusahakan oleh masyarakat setempat.

Penyajian hasil survei ini adalah berupa laporan dan peta. Adapun peta-peta yang dihasilkan yaitu: 1) peta satuan lahan; 2) peta kesesuaian lahan aktual terpilih; dan 3) peta rekomendasi pengembangan tanaman hortikultura.

\section{HASIL DAN PEMBAHASAN}

\section{Satuan Lahan di Daerah Penelitian}

Pendekatan satuan lahan merupakan metode interpretasi yang berbasis fisiografi untuk membantu pemahaman awal dari kenampakan perbedaan karakteristik penyusun lahan di suatu wilayah. Pendekatan ini didasari pada kombinasi dari kesamaan beberapa karakteristik komponen penyusunan suatu wilayah yang meliputi bentuk wilayah dan kemiringan lereng, bahan induk (litologi), tanah dan penggunaan lahan lokasi penelitian. Pembagian komponen penyusun satuan lahan di Desa Hative Besar Kecamatan Teluk Ambon yaitu terdiri atas:

Bentuk lahan: Dataran Rendah $(\mathrm{P})=$ Plain (ketinggian $<50 \mathrm{~m} \mathrm{dpl}$ ); Perbukitan rendah $(\mathrm{H})=$ Hilly (ketinggian 50-100m dpl); dan Pegunungan (M) = Mountain (ketinggian $>100 \mathrm{~m} \mathrm{dpl}$ ).

Lereng: $\mathrm{L} 0=0-3 \%=$ Dataran; $\mathrm{L} 1=3-8 \%=$ Berombak; L2 $=8-15 \%=$ Bergelombang; L3 $=15-30 \%=$ Agak curam; L4 $=30-65 \%=$ Curam; L5 $=>65 \%=$ Sangat curam.

Bahan induk: 1 = Aluvium; $2=$ Tuff $/$ Los material; $3=$ Batu gamping; 4 = Andesit; dan 5 = Batu pasir.

Penggunaan lahan: 1 = Hutan; 2 = Kebun campuran; 3 $=$ Pemukiman dan lahan pekarangan; dan $4=$ Alangalang, semak dan tegalan.

Berdasarkan hasil pengamatan di lapangan, maka satuan lahan yang didapat di Desa Hative Besar Kecamatan Teluk Ambon dapat dikelompokkan sebagai berikut (Lihat Tabel 1 dan peta satuan lahan/Gambar 1)

\section{Pegunungan}

Pegunungan terbentuk dari batuan induk/ bahan induk Andesit. Berdasarkan geologi, bentuk lahan, kemiringan lereng dan penggunaan lahan, satuan lahan ini dapat dibagi atas Satuan lahan M4L52 dan M4L44.

\section{Perbukitan Rendah}

Perbukitan rendah terbentuk atas batuan Tuff/bahan lepas dan batu pasir. Karakteristik satuan lahan $\mathrm{H}$ ini tidak jauh berbeda dengan karakteristik pada daerah pegunungan atau satuan lahan M. Berdasarkan geologi, bentuk lahan, kemiringan lereng dan penggunaan lahannya, satuan lahan ini dapat dibagi atas Satuan lahan H2L32, H2L42, H2L52, H5L32, H5L33 dan H5L42.

\section{Dataran Rendah}

Dataran rendah terbentuk atas batuan Aluvium. Berdasarkan geologi, bentuk lahan, kemiringan lereng dan penggunaan lahannya, satuan lahan ini dapat dibagi atas Satuan lahan P1L13, P1L03, P1L02 dan P1L12.

\section{Kesesuaian Lahan Tanaman Hortikultura di Desa Hative Besar Kecamatan Teluk Ambon}

Evaluasi kesesuaian lahan dilakukan dengan menggunakan metode pencocokan (matching) antara persyaratan tumbuh tanaman yang diusahakan yang ada dalam kriteria kelas kesesuaian lahan dengan karakteristik lahan pada masing-masing unit lahan yang 
ada di lokasi penelitian (Djaenudin et al., 2011). Namun tidak semua sifat fisik lahan atau karakteristik dan kualitas lahan yang diamati dalam penelitian ini. Untuk sifat fisik lahan yang diamati di lapangan hanya terbatas pada beberapa sifat berikut yakni ketersediaan oksigen (drainase), media perakaran (tekstur dan kedalaman tanah) dan bahaya erosi (lereng), sedangkan untuk sifat kimia yang langsung diamati di lapangan tanpa melewati analisis laboratorium yakni retensi hara $\mathrm{pH}$ dan $\mathrm{c}$ organik). Data fisik lapangan tersebut termasuk dalam data primer dan untuk data sekunder yang diperoleh dari Stasiun Meteorologi Pattimura Ambon (tahun 20062015) diketahui bahwa lokasi penelitian ini memiliki iklim yang seragam atau berada di dalam satu zona sehingga menurut Oldeman (1975) tipe iklim di lokasi penelitian termasuk dalam tipe iklim $\mathrm{C} 1$ dengan curah hujan $3725 \mathrm{~mm} /$ tahun.

Adapun tanaman yang dievaluasi dalam penelitian ini meliputi rambutan, gandaria, durian,duku, nenas dan manggis. Penilaian kesesuaian lahan dilakukan melalui dua tahapan yaitu dinilai untuk kondisi saat ini (kesesuaian lahan aktual) dan setelah diadakan perbaikan (kesesuaian lahan potensial) (Ritung et al., 2007). Dari penilaian kesesuaian lahan aktual, aktual terpilih serta kesesuaian lahan potensial maka dapat diketahui jenis tanaman hortikultura buahan yang hasil kecocokannya sesuai dengan karakteristik dan kualitas lahan lokasi penelitian. Selain itu jua dapat direkomendasikan tindakan atau usaha perbaikan terhadap masing-masing faktor pembatas pada setiap satuan lahan yang ada di lokasi penelitian.

\section{Karakteristik dan Kualitas Lahan Desa Hative Besar}

Karakteristik dan kualitias lahan yang diamati di lapangan maupun diperoleh dari data sekunder yang diuraikan pada tabel 2 adalah sebagai berikut: suhu $\left({ }^{\circ} \mathrm{C}\right)$, ketersediaan air (curah hujan dan kelembaban), ketersediaan oksigen (drainase tanah), media perakaran (tekstur tanah, kedalaman atau solum tanah), retensi hara ( $\mathrm{pH}$ tanah dan kandungan c-organik) dan tingkat bahaya erosi (kelerengan). uraian karakteristik dan kualitas lahan yang dijumpai pada masing-masing satuan lahan di lokasi penelitian dapat dilihat pada Tabel 2.

Tabel 1. Satuan Lahan Lokasi Penelitian

\begin{tabular}{|c|c|c|c|c|c|c|c|c|}
\hline \multirow[b]{2}{*}{ No } & \multicolumn{4}{|c|}{ Uraian } & \multirow[b]{2}{*}{ Jenis Tanah } & \multirow[b]{2}{*}{$\begin{array}{c}\text { Kode } \\
\text { SL }\end{array}$} & \multicolumn{2}{|c|}{ Luas } \\
\hline & $\begin{array}{l}\text { Bentuk } \\
\text { lahan }\end{array}$ & Lereng & $\begin{array}{l}\text { Bahan } \\
\text { Induk }\end{array}$ & Penggunaan Lahan & & & $\mathrm{Ha}$ & $\%$ \\
\hline 1. & $\begin{array}{l}\text { Pegununga } \\
\mathrm{n}(\mathrm{M})\end{array}$ & $49 \%$ & Andesit & Kebun campuran & $\begin{array}{l}\text { Kambisol } \\
\text { (Inceptisol) }\end{array}$ & M4L52 & 68,03 & 5,87 \\
\hline 2. & & $42 \%$ & Andesit & $\begin{array}{l}\text { Hutan Sekunder, semak } \\
\text { belukar, alang-alang }\end{array}$ & $\begin{array}{l}\text { Kambisol } \\
\text { (Inceptisol) }\end{array}$ & M4L44 & 61,61 & 5,32 \\
\hline 3. & $\begin{array}{l}\text { Perbukitan } \\
\text { Rendah (H) }\end{array}$ & $30 \%$ & $\begin{array}{l}\text { Tuff/ Los } \\
\text { material }\end{array}$ & $\begin{array}{l}\text { Kebun campuran } \\
\text { (dominan gandaria) }\end{array}$ & $\begin{array}{l}\text { Kambisol } \\
\text { (Inceptisol) }\end{array}$ & H2L32 & 12,47 & 1,07 \\
\hline 4. & & $32 \%$ & $\begin{array}{l}\text { Tuff/ Los } \\
\text { material }\end{array}$ & $\begin{array}{l}\text { Kebun campuran } \\
\text { (dominan pala) }\end{array}$ & $\begin{array}{l}\text { Kambisol } \\
\text { (Inceptisol) }\end{array}$ & H2L42 & 299,54 & 25,87 \\
\hline 5. & & $55 \%$ & $\begin{array}{l}\text { Tuff/ Los } \\
\text { material }\end{array}$ & $\begin{array}{l}\text { Kebun campuran } \\
\text { (dominan pisang) }\end{array}$ & $\begin{array}{l}\text { Kambisol } \\
\text { (Inceptisol) }\end{array}$ & H2L52 & 35,47 & 3,06 \\
\hline 6. & & $18 \%$ & $\begin{array}{l}\text { Batu } \\
\text { Pasir }\end{array}$ & $\begin{array}{l}\text { Kebun campuran } \\
\text { (dominan nenas) }\end{array}$ & $\begin{array}{l}\text { Kambisol } \\
\text { (Inceptisol) }\end{array}$ & H5L32 & 57,51 & 4,96 \\
\hline 7. & & $15 \%$ & $\begin{array}{l}\text { Batu } \\
\text { Pasir }\end{array}$ & $\begin{array}{l}\text { Kebun campuran } \\
\text { (dominan gandaria) }\end{array}$ & $\begin{array}{l}\text { Kambisol } \\
\text { (Inceptisol) }\end{array}$ & H5L33 & 54,75 & 4,72 \\
\hline 8. & & $35 \%$ & $\begin{array}{l}\text { Batu } \\
\text { Pasir }\end{array}$ & Kebun campuran & $\begin{array}{l}\text { Kambisol } \\
\text { (Inceptisol) }\end{array}$ & H5L42 & 469,62 & 40,56 \\
\hline 9. & Dataran $(\mathrm{P})$ & $5 \%$ & Aluvium & $\begin{array}{l}\text { Pemukiman dan lahan } \\
\text { pekarangan }\end{array}$ & $\begin{array}{l}\text { Aluvial } \\
\text { (Entisol) }\end{array}$ & P1L13 & 15,51 & 1,33 \\
\hline 10. & & $3 \%$ & Aluvium & $\begin{array}{l}\text { Pemukiman dan lahan } \\
\text { pekarangan }\end{array}$ & $\begin{array}{l}\text { Aluvial } \\
\text { (Entisol) }\end{array}$ & P1L03 & 55,39 & 4,78 \\
\hline 11. & & $3 \%$ & Aluvium & $\begin{array}{l}\text { Pemukiman dan lahan } \\
\text { pekarangan }\end{array}$ & $\begin{array}{l}\text { Aluvial } \\
\text { (Entisol) }\end{array}$ & P1L02 & 21,76 & 1,87 \\
\hline 12. & & $4 \%$ & Aluvium & $\begin{array}{l}\text { Pemukiman dan lahan } \\
\text { pekarangan }\end{array}$ & $\begin{array}{l}\text { Aluvial } \\
\text { (Entisol) }\end{array}$ & P1L12 & 5,9 & 0,50 \\
\hline Total & & & & & & & 1157,56 & 100 \\
\hline
\end{tabular}




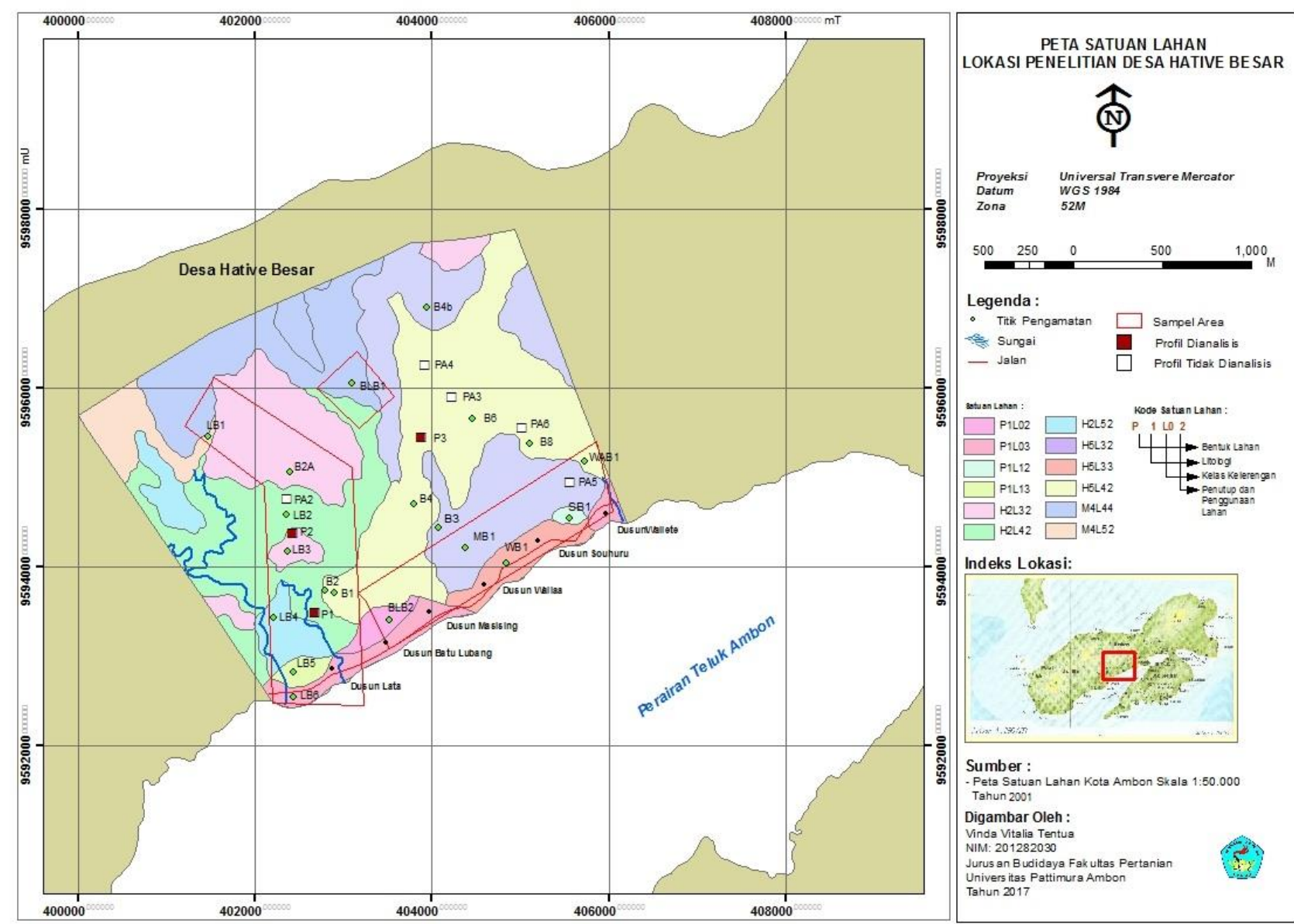

Gambar 1. Peta Satuan Lahan Lokasi Penelitian Desa Hative Besar

Tabel 2. Karakteristik Lahan di Desa Hative Besar Kecamatan Teluk Ambon

\begin{tabular}{|c|c|c|c|c|c|c|c|c|c|c|}
\hline \multirow[b]{2}{*}{ SL } & \multirow{2}{*}{$\begin{array}{c}\text { Suhu (t) } \\
\text { Suhu } \\
\left({ }^{\circ} \mathrm{C}\right)\end{array}$} & \multicolumn{2}{|c|}{ Ketersediaan Air (w) } & \multicolumn{3}{|c|}{ Media Perakaran (r) } & \multicolumn{2}{|c|}{ Retensi Hara (f) } & \multicolumn{2}{|c|}{ Bahaya Erosi (s) } \\
\hline & & $\begin{array}{c}\text { Curah Hujan } \\
(\mathrm{mm})\end{array}$ & $\begin{array}{c}\text { Kelembaban } \\
\text { Nisbih }(\%)\end{array}$ & Drainase & Tekstur & $\begin{array}{l}\text { Kedalaman } \\
\text { Tanah }(\mathrm{cm})\end{array}$ & $\mathrm{pH} \mathrm{H} \mathrm{H}_{2} \mathrm{O}$ & C-Organik & $\begin{array}{c}\text { Lereng } \\
(\%)\end{array}$ & $\begin{array}{c}\text { Bahaya } \\
\text { Erosi }\end{array}$ \\
\hline $\mathrm{H}_{2} \mathrm{~L}_{3} 2$ & 24,2 & 3725 & 78 & Baik & $\mathrm{Sdg}-\mathrm{H}$ & $>65$ & $4-5$ & $\begin{array}{l}\text { Banyak - } \\
\text { Sedikit }\end{array}$ & $30 \%$ & Berat \\
\hline $\mathrm{H}_{2} \mathrm{~L}_{4} 2$ & 24,2 & 3725 & 78 & Baik & $\mathrm{Sdg}-\mathrm{H}$ & $>68$ & $4-6$ & $\begin{array}{l}\text { Banyak - } \\
\text { Tdk Ada }\end{array}$ & $32 \%$ & Berat \\
\hline $\mathrm{H} 2 \mathrm{~L}_{5} 2$ & 24,2 & 3725 & 78 & Baik & $\mathrm{Sdg}-\mathrm{H}$ & $>53$ & 4 & $\begin{array}{l}\text { Sedikit - } \\
\text { Tdk Ada }\end{array}$ & $55 \%$ & $\begin{array}{c}\text { Sangat } \\
\text { Berat }\end{array}$ \\
\hline $\mathrm{P}_{1} \mathrm{~L}_{1} 3$ & 24,2 & 3725 & 78 & $\begin{array}{l}\text { Agak } \\
\text { Buruk }\end{array}$ & $\mathrm{Sdg}-\mathrm{K}$ & $>75$ & $4-6$ & $\begin{array}{l}\text { Banyak - } \\
\text { Sedikit }\end{array}$ & $5 \%$ & $\begin{array}{l}\text { Sangat } \\
\text { Ringan }\end{array}$ \\
\hline $\mathbf{P}_{1} \mathrm{~L}_{0} 3$ & 24,2 & 3725 & 78 & Baik & $\mathrm{K}$ & $>56$ & $5-7$ & $\begin{array}{l}\text { Sedikit - } \\
\text { Tdk Ada }\end{array}$ & $3 \%$ & Ringan \\
\hline $\mathrm{M}_{4} \mathrm{~L}_{5} 2$ & 24,2 & 3725 & 78 & Baik & $\mathrm{Sdg}-\mathrm{H}$ & $>91$ & 4,6 & $\begin{array}{l}\text { Banyak - } \\
\text { Tdk Ada }\end{array}$ & $49 \%$ & $\begin{array}{c}\text { Sangat } \\
\text { Berat }\end{array}$ \\
\hline $\mathrm{M}_{4} \mathrm{~L}_{4} 4$ & 24,2 & 3725 & 78 & Baik & $\mathrm{Sdg}-\mathrm{K}$ & $>95$ & $4-6$ & $\begin{array}{l}\text { Banyak - } \\
\text { Tdk Ada }\end{array}$ & $42 \%$ & $\begin{array}{c}\text { Sangat } \\
\text { Berat }\end{array}$ \\
\hline $\mathrm{P}_{1} \mathrm{~L}_{0} 2$ & 24,2 & 3725 & 78 & $\begin{array}{l}\text { Agak } \\
\text { Buruk }\end{array}$ & $\mathrm{K}$ & $>40$ & $6-7$ & $\begin{array}{l}\text { Banyak - } \\
\text { Tdk Ada }\end{array}$ & $3 \%$ & Ringan \\
\hline $\mathrm{H}_{5} \mathrm{~L}_{3} 2$ & 24,2 & 3725 & 78 & Baik & $\mathrm{Sdg}-\mathrm{H}$ & $>62$ & $4-5$ & Tdk Ada & $18 \%$ & Berat \\
\hline $\mathrm{H}_{5} \mathrm{~L}_{3} 3$ & 24,2 & 3725 & 78 & Baik & $\mathrm{Sdg}$ & $>62$ & $5-6$ & $\begin{array}{l}\text { Banyak - } \\
\text { Sedikit }\end{array}$ & $15 \%$ & Sedang \\
\hline $\mathrm{P}_{1} \mathrm{~L}_{1} 2$ & 24,2 & 3725 & 78 & $\begin{array}{l}\text { Agak } \\
\text { Buruk }\end{array}$ & K & $>53$ & 6 & $\begin{array}{l}\text { Banyak - } \\
\text { Sedikit }\end{array}$ & $4 \%$ & Ringan \\
\hline $\mathrm{H}_{5} \mathrm{~L}_{4} 2$ & 24,2 & 3725 & 78 & Baik & $\mathrm{Sdg}-\mathrm{H}$ & $>38$ & 4 & Sdkt & $35 \%$ & Berat \\
\hline
\end{tabular}




\section{Penilaian Kesesuaian Lahan Aktual Untuk Komoditas Hortikultura Yang Diusahakan di Desa Hative Besar}

Klasifikasi kesesuaian lahan aktual adalah sistem klasifikasi kesesuaian lahan yang pengelompokannya didasarkan pada karakteristik lahan yang ada pada saat itu, tanpa mempertimbangkan input atau masukan yang dibutuhkan (Tufaila dan Alam, 2014). Faktor-faktor pembatas dalam evaluasi lahan dibedakan atas faktor pembatas yang bersifat permanen dan non permanen (dapat diperbaiki). Faktor pembatas yang bersifat permanen merupakan pembatas yang tidak memungkinkan untuk dapat diperbaiki dan kalaupun dapat diperbaiki, secara ekonomis sangat tidak menguntungkan.

\section{Rekomendasi Tindakan Perbaikan Untuk Tiap Faktor Pembatas}

Tindakan pengelolaan lahan di wilayah penelitian ditujukan terutama terhadap faktor-faktor pembatas yang menjadi penghambat bagi pertumbuhan tanaman (Selassie et al., 2014). Faktor pembatas merupakan kualitas dan karakteristik lahan dominan yang membatasi kemampuan tumbuh dengan baik suatu jenis tanaman.

Berdasarkan hasil klasifikasi kesesuaian lahan aktual, yang menjadi faktor penghambat bagi pertumbuhan tanaman yang terdapat pada Desa Hative Besar Kecamatan Teluk Ambon meliputi ketersediaan air yaitu curah hujan serta karakteristik tanah berupa media perakaran (tekstur tanah dan kedalaman atau solum tanah), tingkat bahaya erosi yaitu lereng dan ketersediaan oksigen yaitu drainase.
Curah hujan merupakan faktor pembatas yang sangat sulit untuk diperbaiki karena bersifat permanen (Widiatmaka et al., 2014) sedangkan faktor pembatas karakteristik tanah dapat diperbaiki dengan tindakan pengelolaan konservasi tanah meliputi pembuatan teras, penanaman menurut kontur, dan penanaman tanaman penutup tanah untuk mencegah laju erosi pada lahanlahan yang kelas lerengnya agak curam, curam sampai sangat curam, namun ini membutuhkan biaya yang tinggi. Dan untuk mengatasi faktor pembatas Drainase Tanah dari agak buruk - sangat buruk maka diperlukan upaya untuk membuat saluran-saluran drainase.

\section{Penilaian Kesesuaian Lahan Potensial Untuk Komoditas Hortikultura Yang Diusahakan di Desa Hative Besar}

Penilaian kesesuaian lahan potensial merupakan analisis lanjutan dari penilaian sebelumnya (kesuaian aktual), dimana dilakukan upaya perbaikan/ upaya pengelolaan lahan yang menjadi faktor pembatas kelas kesesuaian aktual. Uraian penilaian kesesuaian lahan aktual dan potensial disajikan pada tabel 3 .

\section{Kesesuaian Lahan Aktual Terpilih}

Kesesuaian lahan aktual terpilih merupakan pilihan penggunaan kesesuaian yang lebih tepat dari suatu satuan lahan. Setelah evaluasi kesesuaian lahan dari masing-masing satuan lahan maka akan dihasilkan kesesuaian lahan aktual terpilih untuk enam tanaman hortikultura yang diusahakan di Desa Hative Besar seperti tertera pada Tabel 4 .

Tabel 3. Kelas dan Sub Kelas Kesesuaian Lahan Untuk Tanaman Hortikultura

\begin{tabular}{|c|c|c|c|c|c|c|c|c|c|c|c|c|}
\hline \multirow{2}{*}{$\begin{array}{c}\text { Kode } \\
\text { SL }\end{array}$} & \multicolumn{6}{|c|}{ Kesesuaian Lahan Aktual } & \multicolumn{6}{|c|}{ Kesesuaian Lahan Potensial } \\
\hline & $\mathrm{Ra}$ & $\mathrm{Ga}$ & $\mathrm{Du}$ & Dl & $\mathrm{Ma}$ & $\mathrm{Ne}$ & $\mathrm{Ra}$ & $\mathrm{Ga}$ & $\mathrm{Du}$ & Dl & $\mathrm{Ma}$ & $\mathrm{Ne}$ \\
\hline M4L52 & $\mathrm{N}$ & $\mathrm{N}$ & $\mathrm{N}$ & $\mathrm{N}$ & $\mathrm{N}$ & $\mathrm{N}$ & $\mathrm{N}$ & $\mathrm{N}$ & $\mathrm{N}$ & $\mathrm{N}$ & $\mathrm{N}$ & $\mathrm{N}$ \\
\hline M4L44 & $\mathrm{N}$ & $\mathrm{N}$ & $\mathrm{N}$ & $\mathrm{N}$ & $\mathrm{N}$ & $\mathrm{N}$ & $\mathrm{N}$ & $\mathrm{N}$ & $\mathrm{N}$ & $\mathrm{N}$ & $\mathrm{N}$ & $\mathrm{N}$ \\
\hline H2L32 & S3w,r,s & $\mathrm{S} 3 \mathrm{w}, \mathrm{r}, \mathrm{s}$ & $\mathrm{S} 3 \mathrm{w}, \mathrm{s}$ & S3w,r,s & $\mathrm{N}$ & $\mathrm{S} 3 \mathrm{w}, \mathrm{s}$ & $\begin{array}{l}\text { S2w,s } \\
\text { S3r }\end{array}$ & $\begin{array}{l}\text { S2w,s } \\
\text { S3r }\end{array}$ & $\mathrm{S} 2 \mathrm{w}, \mathrm{s}$ & $\begin{array}{l}\text { S2w,s } \\
\text { S3r }\end{array}$ & $\mathrm{N}$ & $\mathrm{S} 2 \mathrm{w}, \mathrm{s}$ \\
\hline H2L42 & $\mathrm{N}$ & $\mathrm{N}$ & $\mathrm{S} 3 \mathrm{w}, \mathrm{s}$ & S3w,r,s & $\mathrm{N}$ & $\mathrm{N}$ & $\mathrm{N}$ & $\mathrm{N}$ & $\mathrm{S} 2 \mathrm{w}, \mathrm{s}$ & $\begin{array}{l}\text { S2w,s } \\
\text { S3r }\end{array}$ & $\mathrm{N}$ & $\mathrm{N}$ \\
\hline H2L52 & $\mathrm{N}$ & $\mathrm{N}$ & $\mathrm{N}$ & $\mathrm{N}$ & $\mathrm{N}$ & $\mathrm{N}$ & $\mathrm{N}$ & $\mathrm{N}$ & $\mathrm{N}$ & $\mathrm{N}$ & $\mathrm{N}$ & $\mathrm{N}$ \\
\hline H5L32 & $\begin{array}{l}\mathrm{S} 3 \mathrm{w}, \\
\mathrm{r}, \mathrm{s}\end{array}$ & $\begin{array}{l}\mathrm{S} 3 \mathrm{w}, \\
\mathrm{r}, \mathrm{s}\end{array}$ & $\begin{array}{l}\mathrm{S} 3 \mathrm{w}, \\
\mathrm{r}, \mathrm{s}\end{array}$ & $\begin{array}{l}\mathrm{S} 3 \mathrm{w}, \\
\mathrm{r}, \mathrm{s}\end{array}$ & $\mathrm{N}$ & $\mathrm{S} 3 \mathrm{w}, \mathrm{s}$ & $\begin{array}{l}\text { S2w,s } \\
\text { S3r }\end{array}$ & $\begin{array}{l}\text { S2w,s } \\
\text { S3r }\end{array}$ & $\begin{array}{l}\text { S2w,s } \\
\text { S3r }\end{array}$ & $\begin{array}{l}\text { S2w,s } \\
\text { S3r }\end{array}$ & $\mathrm{N}$ & $\mathrm{S} 2 \mathrm{w}, \mathrm{s}$ \\
\hline H5L33 & $\mathrm{S} 2 \mathrm{r}$ & $\mathrm{S} 2 \mathrm{r}$ & $\mathrm{S} 2 \mathrm{r}$ & $\mathrm{S} 2 \mathrm{r}$ & $\mathrm{N}$ & $\mathrm{S} 2 \mathrm{r}$ & $\mathrm{S} 2 \mathrm{r}$ & $\mathrm{S} 2 \mathrm{r}$ & $\mathrm{S} 2 \mathrm{r}$ & $\mathrm{S} 2 \mathrm{r}$ & $\mathrm{N}$ & $\mathrm{S} 2 \mathrm{r}$ \\
\hline H5L42 & $\mathrm{N}$ & $\mathrm{N}$ & $\mathrm{N}$ & S3w,s & $\mathrm{N}$ & $\mathrm{N}$ & $\mathrm{N}$ & $\mathrm{N}$ & $\mathrm{N}$ & $\mathrm{S} 2 \mathrm{w}, \mathrm{s}$ & $\mathrm{N}$ & $\mathrm{N}$ \\
\hline P1L13 & $\mathrm{S} 3 \mathrm{w}, \mathrm{r}$ & S3w,r & S3w & S3w & $\mathrm{N}$ & S3w & $\begin{array}{l}\text { S2w } \\
\text { S3r }\end{array}$ & $\begin{array}{l}\text { S2w } \\
\text { S3r }\end{array}$ & S2w & S2w & $\mathrm{N}$ & $\mathrm{S} 2 \mathrm{w}$ \\
\hline P1L03 & $\mathrm{N}$ & $\mathrm{N}$ & $\mathrm{N}$ & $\mathrm{N}$ & $\mathrm{N}$ & $\mathrm{N}$ & $\mathrm{N}$ & $\mathrm{N}$ & $\mathrm{N}$ & $\mathrm{N}$ & $\mathrm{N}$ & $\mathrm{N}$ \\
\hline P1L02 & $\mathrm{N}$ & $\mathrm{N}$ & $\mathrm{N}$ & $\mathrm{N}$ & $\mathrm{N}$ & $\mathrm{N}$ & $\mathrm{N}$ & $\mathrm{N}$ & $\mathrm{N}$ & $\mathrm{N}$ & $\mathrm{N}$ & $\mathrm{N}$ \\
\hline P1L12 & $\mathrm{N}$ & $\mathrm{N}$ & $\mathrm{N}$ & $\mathrm{N}$ & $\mathrm{N}$ & $\mathrm{N}$ & $\mathrm{N}$ & $\mathrm{N}$ & $\mathrm{N}$ & $\mathrm{N}$ & $\mathrm{N}$ & $\mathrm{N}$ \\
\hline
\end{tabular}

Keterangan: Ra = Rambutan; Ga = Gandaria; Du = Durian; Dl = Duku Landsat; Ma = Manggis; Ne = Nenas; wa = Water availability (Ketersediaan Air); r = Rooting Condition (Keadaan Akar); s = Erosion hazard (Bahaya Erosi) 
Tabel 4. Kesesuaian Lahan Aktual Terpilih Untuk Tanaman Hortikultura

\begin{tabular}{|c|c|c|c|c|c|c|c|}
\hline Satuan Lahan & Rambutan & Gandaria & Durian & Duku & Manggis & Nenas & $\begin{array}{c}\text { Kesesuaian } \\
\text { Aktual } \\
\text { Terpilih } \\
\end{array}$ \\
\hline M4L52 & $\mathrm{N}$ & $\mathrm{N}$ & $\mathrm{N}$ & $\bar{N}$ & $\mathrm{~N}$ & $\mathrm{~N}$ & $\mathrm{~N}$ \\
\hline $\mathrm{M} 4 \mathrm{~L}_{4} 4$ & $\mathrm{~N}$ & $\mathrm{~N}$ & $\mathrm{~N}$ & $\mathrm{~N}$ & $\mathrm{~N}$ & $\mathrm{~N}$ & $\mathrm{~N}$ \\
\hline $\mathrm{H} 2 \mathrm{~L}_{3} 2$ & $\mathrm{~S} 3 \mathrm{w}, \mathrm{r}, \mathrm{s}$ & S3w,r,s & S3w,s & $\mathrm{S} 3 \mathrm{w}, \mathrm{r}, \mathrm{s}$ & $\mathrm{N}$ & $\begin{array}{c}\text { S3w } \\
\text { S2s }\end{array}$ & $\mathrm{S} 3 \mathrm{w}, \mathrm{s}$ \\
\hline $\mathrm{H} 2 \mathrm{~L}_{4} 2$ & $\mathrm{~N}$ & $\mathrm{~N}$ & S3w,s & $\mathrm{S} 3 \mathrm{w}, \mathrm{r}, \mathrm{s}$ & $\mathrm{N}$ & $\mathrm{N}$ & S3w, s \\
\hline $\mathrm{H} 2 \mathrm{~L}_{5} 2$ & $\mathrm{~N}$ & $\mathrm{~N}$ & $\mathrm{~N}$ & $\mathrm{~N}$ & $\mathrm{~N}$ & $\mathrm{~N}$ & $\mathrm{~N}$ \\
\hline $\mathrm{H}_{5} \mathrm{~L}_{3} 2$ & $\mathrm{~S} 3 \mathrm{w}, \mathrm{r}, \mathrm{s}$ & $\mathrm{S} 3 \mathrm{w}, \mathrm{r}, \mathrm{s}$ & $\mathrm{S} 3 \mathrm{w}, \mathrm{r}, \mathrm{s}$ & $\mathrm{S} 3 \mathrm{w}, \mathrm{r}, \mathrm{s}$ & $\mathrm{N}$ & S3w,s & $\mathrm{S} 3 \mathrm{w}, \mathrm{s}$ \\
\hline $\mathrm{H}_{5} \mathrm{~L}_{3} 3$ & S2r & S2r & S2r & S2r & $\mathrm{N}$ & $\mathbf{S} 2 \mathbf{r}$ & S2r \\
\hline $\mathrm{H}_{5} \mathrm{~L}_{4} 2$ & $\mathrm{~N}$ & $\mathrm{~N}$ & $\mathrm{~N}$ & S3w,s & $\mathrm{N}$ & $\mathrm{N}$ & $\mathrm{S} 3 \mathrm{w}, \mathrm{s}$ \\
\hline $\mathrm{P} 1 \mathrm{~L}_{1} 3$ & S3w, r & S3w, r & S3w & S3w & $\mathrm{N}$ & S3w & S3w \\
\hline $\mathrm{P} 1 \mathrm{~L}_{0} 3$ & $\mathrm{~N}$ & $\mathrm{~N}$ & $\mathrm{~N}$ & $\mathrm{~N}$ & $\mathrm{~N}$ & $\mathrm{~N}$ & $\mathrm{~N}$ \\
\hline $\mathrm{P} 1 \mathrm{~L}_{0} 2$ & $\mathrm{~N}$ & $\mathrm{~N}$ & $\mathrm{~N}$ & $\mathrm{~N}$ & $\mathrm{~N}$ & $\mathrm{~N}$ & $\mathrm{~N}$ \\
\hline $\mathrm{P} 1 \mathrm{~L}_{1} 2$ & $\mathrm{~N}$ & $\mathrm{~N}$ & $\mathrm{~N}$ & $\mathrm{~N}$ & $\mathrm{~N}$ & $\mathrm{~N}$ & $\mathrm{~N}$ \\
\hline
\end{tabular}

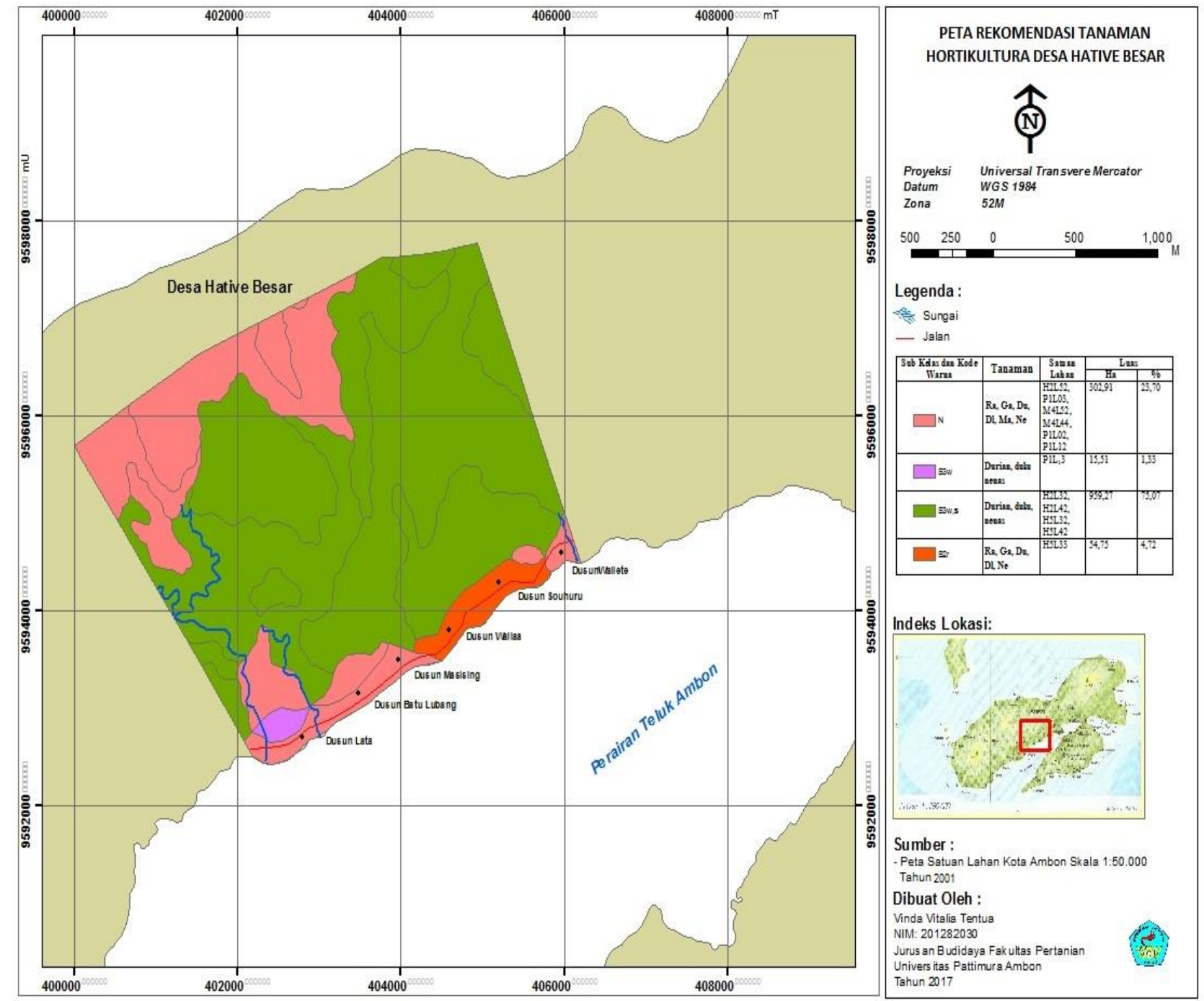

Gambar 2. Peta Rekomendasi Tanaman Hortikultura Desa Hative Besar 


\section{KESIMPULAN}

Berdasarkan hasil penelitian dan pembahasan di atas maka dapat disimpulkan bahwa:

1. Berdasarkan hasil penilaian kesesuaian lahan aktual diketahui bahwa tanaman rambutan, gandaria, durian, duku dan nenas termasuk dalam kelas kesesuaian S3 (sesuai marginal) dengan empat faktor pembatas utama yakni ketersediaan air (w), media perakaran (r) dan bahaya erosi (s). Sedangkan tanaman manggis termasuk dalam kelas kesesuaian $\mathrm{N}$ (tidak sesuai). Berdasarkan penilaian kesesuaian lahan potensial diketahui bahwa terdapat lima tanaman yang sesuai yakni tanaman rambutan, gandaria, durian dan duku termasuk dalam kelas kesesuaian S2 (cukup sesuai) dengan sub kelas S2w,s dan S3 (sesuai marginal) dengan sub kelas S3rc pada satuan lahan $\mathrm{H}_{2} \mathrm{~L}_{3} 2, \mathrm{H}_{2} \mathrm{~L}_{4} 2, \mathrm{P}_{1} \mathrm{~L}_{1} 3 \mathrm{H}_{5} \mathrm{~L}_{3} 2$ dan $\mathrm{H}_{5} \mathrm{~L}_{4} 2$. Kemudian pada satuan lahan $\mathrm{H}_{5} \mathrm{~L}_{3} 3$ dengan sub kelas S2r. Dan tanaman nenas yang termasuk dalam kelas S2 (cukup sesuai) dengan sub kelas $\mathrm{S} 2 \mathrm{w}$,s pada satuan lahan $\mathrm{H}_{2} \mathrm{~L}_{3} 2$, $\mathrm{P}_{1} \mathrm{~L}_{1} 3$ dan $\mathrm{H}_{5} \mathrm{~L}_{3} 2$. Sedangkan berdasarkan kesesuaian lahan aktual terpilih juga terdapat lima jenis tanaman yang sesuai yakni durian pada satuan lahan $\mathrm{H}_{2} \mathrm{~L}_{3} 2, \mathrm{H}_{2} \mathrm{~L}_{4} 2, \mathrm{H}_{5} \mathrm{~L}_{3} 3$ dan $\mathrm{P}_{1} \mathrm{~L}_{1} 3$ dengan sub kelas S3w,s dan S2r, tanaman duku pada satuan lahan $\mathrm{P}_{1} \mathrm{~L}_{1} 3, \mathrm{H}_{5} \mathrm{~L}_{3} 3$ dan $\mathrm{H}_{5} \mathrm{~L}_{4} 2$ dengan sub kelas S3w,s dan S2r dan tanaman nenas pada satuan lahan $\mathrm{H}_{2} \mathrm{~L}_{3} 2, \mathrm{H}_{5} \mathrm{~L}_{3} 3, \mathrm{P} 1 \mathrm{~L}_{1} 3$ dan $\mathrm{H}_{5} \mathrm{~L}_{3} 2$ dengan sub kelas S3w,s dan S2r.

2. Faktor-faktor karakteristik dan kualitas lahan yang menjadi faktor pembatas terhadap pertumbuhan tanaman hortikultura di lokasi penelitian yakni: faktor ketersediaan air (w) dalam hal ini curah hujan, media perakaran (r) dalam hal ini tekstur dan kedalaman tanah dan bahaya erosi (s) dalam hal ini kelerengan.

3. Berdasarkan pada penilaian kesesuaian aktual terpilih untuk setiap komoditi tanaman hortikultura di Desa Hative Besar maka penulis merekomendasikan beberapa komoditi tanaman yang dianggap sesuai berdasarkan penilaian kesesuaian aktual terpilih yakni tanaman rambutan dan gandaria yang dapat dibudidayakan pada satuan lahan H5L33 karena tingkat kesesuaiannya termasuk kedalam kelas cukup sesuai (S2) dengan sub kelas S2r, tanaman durian dapat dibudidayakan pada satuan lahan H2L32, H2L42, H5L33, dan P1L13, tanaman duku dapat dibudidayakan pada satuan lahan H5L33, H5L42, dan P1L13, dan tanaman nenas dapat dibudidayakan pada satuan lahan H2L32, H5L32, H5L33, dan P1L13. Sedangkan berdasarkan hasil penilaian kesesuaian lahan aktual terpilih untuk tanaman manggis, diketahui bahwa tanaman ini tidak sesuai untuk dibudidayakan karena memiliki faktor pembatas terberat yakni ketersediaan air (curah hujan).

\section{DAFTAR PUSTAKA}

Balai Penelitian Tanah. 2003. Petunjuk Teknis Evaluasi Lahan untuk Komoditas Pertanian. Balai Penelitian Tanah. Bogor.

CSR/FAO Staff. 1983. Reconnaissance Land Resource Surveys 1 : 250,000 Scale Atlas Format Procedures. Manual 4, Version 1. Centre for Soil Research, Ministry of Agriculture Government of Indonesia-United Nations Development Programme and Food and Agriculture Organization. Bogor, Indonesia. 106 pp.

Djaenudin, D., Marwan, H., Subagjo, H., dan A. Hidayat. 2011. Petunjuk Teknis Evaluasi Lahan Untuk Komoditas Pertanian. Balai Besar Litbang Sumberdaya Lahan Pertanian, Badan Litbang Pertanian, Bogor. 36p.

Gaspersz, E.J. 2008. Perwilayahan Komoditas Pertanian di Kecamatan Kairatu Kabupaten Seram Bagian Barat Provinsi Maluku. Laporan Penelitian. Fakultas Pertanian. Universitas Pattimura. Ambon.

Mutiara, E. 2015. Kesesuaian lahan untuk tanaman kacang tanah di Desa Sampuran, Kecamatan Ranto Baek Kabupaten Mandailing Natal. Jurnal Nasional Ecopedon 2: 1-4.

Oldeman, L.R. 1975. Agroclimatic Map of Java \& Madura. Contr. of Centra Res. Inst. for Food Crops 16/76. Bogor.

Ritung, S., Wahyunto, F. Agus, dan H. Hidayat. 2007. Panduan Evaluasi Kesesuaian Lahan Dengan Contoh Peta Arahan Penggunaan Lahan Kabupaten Aceh Barat. Balai Penelitian Tanah dan World Agroforestry Centre (ICRAF), Bogor, Indonesia.

Safitri, S. 2015. Evaluasi kesesuaian lahan untuk tanaman Kakao (Theobroma cacao L.) di lahan Politeknik Pertanian Negeri Payakumbuh. Jurnal Nasional Ecopedon 1: 53-55.

Sitorus, S.R.P. 1985. Evaluasi Sumberdaya Lahan. Tarsito, Bandung.

Suprapto. 2010. Analisis Komoditi Unggulan Sektor Pertanian Sebelum dan Selama Otonomi Daerah di Kabupaten Sragen. Tesis. Program Magister Ekonomi dan Studi Pembangunan Fakultas Ekonomi Universitas Sebelas Maret, Surakarta.

Tufaila, M. dan S. Alam. 2014. Karakteristik tanah dan evaluasi lahan untuk pengembangan tanaman padi di Kecamatan Oheo Kabupaten Konawe Utara. Agriplis 24: 854-128. 